\title{
User's Perspective on the Quality of Notary Master Graduates in the Concept of Work
}

\author{
Yetniwati Yetniwati ${ }^{1, *}$ Elita Rahmi ${ }^{2}$, Diana Amir ${ }^{3}$ \\ ${ }^{12}{ }^{3}$ Universitas Jambi, Jambi, Indonesia \\ *Corresponding author.Email: yetniwati@unja.ac.id
}

\begin{abstract}
This paper aims to: 1 . Analyze professional quality of alumni in applying their knowledge in the perspective of the user as alumni partners; 2 . Analyze the professional quality of alumni in the perspective of their employees in the context of work creation. This study used a social systems approach. The results showed that horizontally, it was strongly influenced by the following factors: Professionalism and skills; Attitude and behavior; Accessibility and flexibility; Reliability and Trustworthiness; Reputation and Creadibility; The precautionary principle.The quality of Masters Alumni graduates in the perspective of a vertical user as their superior was strongly influenced by the following factors: ethics, discipline, ability to use digital technology, loyalty to superiors. Meanwhile, from users as subordinate to alumni, the quality of graduation was greatly influenced by: alumni guidance to their employees; loyalty to workers / employees; provision of worker welfare; protection to workers, social aspects of work protection. The conclusion in this paper is that the quality of Notary Masters graduates in the user perspective can be influenced by partnerships both horizontally and vertically.
\end{abstract}

Keywords: User, Graduate, Master of Notary.

\section{INTRODUCTION}

Study program management at the Masters level must continuously improve in order to develop the management of study programs internally and externally, to seek whether the study program is still needed by the job market or vice versa. With the measurement of the alumni job market, various improvements can be made to develop it in the future.

The public opinion that universities only increase unemployment is a "heavy slap" for all study programs of all Higher Education, especially in Indonesia. Therefore, it is time for the study program to realize that whether the alumni produced every year can create jobs or vice versa, only become a burden in Indonesia's development, or the quality of our graduates is difficult to be accepted on the existing job market since they lack knowledge and skills.

The number of alumni produced by the Notary Masters of Jambi University keeps increasing and now at the beginning of 2020 it has reached 130 people and there has never been a comprehensive measurement of work copyright, whereas in January 2022 the accreditation period of the Study Program will end, in accordance with existing provisions, at least at the end June 2021 it must have submitted the Study Program accreditation form to the Higher Education Accreditation Board, therefore preliminary data is needed on the work copyright of Jambi University Master of Notary Alumni in order to further refine of the management that has been carried out by the study program.

It has been known that graduates of the Notary Masters study program cannot only become notaries but can also fill development by becoming advocates, lecturers, legal consultants, judges, prosecutors, legal drafters, company managers and even in government, however, it can be ascertained that the number of them who prefer to become a notary remains high. Although they have to pay quite high fees with the new provisions made by the government and in collaboration with the Indonesian Notary Association (INA) to make the process of becoming a notary public is expensive. This means that the interest in becoming a notary is so great for MKn graduates.

The unique combination of the Notary graduate degree which was originally a Notary Candidate $(\mathrm{CN})$ and changed to Sp1 (Specialist 1) with a standard of 7, was upgraded to a standard 8 with a Masters level, 
meaning that Jambi University's Notary Masters alumni can choose several professions outside of a notary, since they are considered knowledgeable and critical in academics and practice, analytical and able to integrate science in building clauses in creating deed, since in the development of Notary Law there is almost no longer a single field of science that stands alone, notary clauses are requirements with other sciences, either in public law or private law, because the position of a notary is a public official who organizes legal certainty for the parties in society who need an authentic deed and can be used as valid evidence in the event of things that are not desired in the agreement they want.

The Job Creation Survey is strategic and vital for study programs in measuring the knowledge, skills and ethics of alumni in the midst of society, and the facts Jambi University Notary Masters alumni have worked in several notary offices and outside the field (not in the Notary Office), such as: becoming judges, prosecutors, local government employees, Indonesian State-Owned Enterprises, notary office employees, lawyers, banking, private sector, and so on. Indeed, there is work that has been done before they enter Notary Masters students and when they become students and after becoming alumni, meaning that they work with various backgrounds which must also be measured.

The manager of the study program is actually the most responsible person for student graduation, the transition of the waiting period from graduation to working and working professionally is the "heartbeat of the study program" which must be a special note in the implementation of education in Indonesia, so that the current work creations are highly expected by the State become a benchmark in evaluating the existing study programs. It is time for Higher Education to review the quality of graduates, to see their own weaknesses, which results in the existing graduates do not become a burden of development itself, namely waste of Bachelor's and waste of Masters and even waste of Doctorates, because unemployed Masters have a much more problematic impact than unemployed of Junior High School graduates, since Masters graduates have a tendency to be blue-collar workers, finally they are vulnerable to committing various crimes and violations in law and government.

There are six elements of quality service characteristics, namely:

a. Professionalism and skills; become the main criteria for a quality service. Customers believe that HR service providers have professional requirements and expertise that are qualified as well as being able to produce quality products.

b. Attitude and behavior; are aimed at service provider personnel in serving or implementing the process who are very empathetic and ready to help customers.

c. Accessibility and flexibility; processes are designed flexibly to make it easy for customers to access.

d. Reliability and Trustworthiness; good reputation and always maintain customer trust make customers trust and believe that what is provided by the service provider is a quality service.

e. Recovery; when something goes wrong, customers are less anxious and worried as they believe the service provider can help to solve the problem.

f. Reputation and Creadibility; image created by service providers is to maintain the reputation and trust of customers.

In accordance with the existing problems, this research is carried out with a social system approach. This social systems approach views an organization / company is a complex system operating in a complex environment which can be called an external system. This study aims to analyze Alumni professional quality in applying their knowledge in the perspective of the user as alumni partners; and to analyze the professional quality of alumni in the perspective of their employees in terms of work creation.

\section{DISCUSSION}

\subsection{The professional quality of the Notary Masters alumni applies their knowledge in the perspective of the user as an alumni partner}

Profession in The Great Indonesian Dictionary (Kamus Besar Bahasa Indonesia-KKBI) is defined as a work which is based on expertise [1]. The acknowledgement of an expert person can be measured from the viewpoint of service users of work products and scientific works. For alumni of Notary Master, the dominant profession is as Notary and Land Deed Official (Pejabat Pembuat Akta Tanah-PPAT), and does not close to other types of professional work. Alumni as professionals must have characteristics in accordance with the theory of Grunros, namely: Professionalism and skills; Attitude and behavior; Accessibility and flexibility; Reliability and Trustworthiness; Recovery; Reputation and Creadibility.

Professionalism and skills; a Notary and PPAT must have quality expertise, so that service users feel satisfied with their services. Therefore, a professional must be able to convince his users that he is an expert and his services do not disappoint his customers. Its good name image lies 
in the user confidence. The deed he makes must be able to provide legal certainty which avoides disputes.

Attitude and behavior; these characteristics aimed at service provider users in serving or carrying out the process which are very empathic and ready to help customers. The moral attitude of notaries and PPAT for notary positions has been regulated in Notary Office (UUJN), UUPPAT and INI Association Regulations. The moral attitudes that have been regulated include: honesty, embracing the religion of the Almighty God, not having concurrent positions which are prohibited by law, never committing disgraceful acts or prohibited by law, not under interdiction, not in a state of bankruptcy.

Accessibility and flexibility; Professional service providers must be able to make it easy for customers to access flexibly, because they must master technology information, since digital media will provide information very quickly. Today the technology development has led to the digital era 4.0 and even towards 5.0, and keep going on.

Reliability and Trustworthiness; A good or wellknown reputation will result in people coming to become clients, even the previous client can give recommendations to later clients, the service provider is a quality service. If the name of the service provider has been tainted, it will result in the user moving to someone else who they think is better.

The precautionary principle; The principle of prudence of a professional is very necessary, since a professional who makes a mistake can cause harm to the client or the interested party. So in the implication of the prudential principle, the notary must make good and correct deeds; in a quality deed, the contents of the deed must be explained to the parties; the power of proof of the notary deed is perfect [2], strive to make the deed contain legal certainty.

Reputation and Creadibility; Good reputation of a notary / PPAT is very influential for interested people who intend to come in making deeds. The image created by service providers is to maintain the reputation and trust of customers.

\subsection{The professional quality of the Notary Master alumni in the perspective of their employees in the context of work creation}

Work agreements are made in form of written and not written or oral. Indeed, there is no requirement in notarial regulations that stipulate a written work agreement, however a written agreement makes easier to prove, and the parties will find it easier to know their rights and obligations.

The relationship between notary / PPAT and employees feels comfortable with alumni. Comfort by meant here is the relationship of behavior, courtesy between employees and alumni.

Obligations of Notary / PPAT in providing guidance should be held at the beginning of work. Indeed, at the beginning of the agreement it was agreed that the parties should know their rights and obligations, so guidance is very important to make employees know which actions can be done, prohibited, and allowed.

The salaries of dominant alumni employees paid cannot be lower than the Minimum Wage of Jambi Province. According to Article 90 of Law No.13 / 2003, employers are prohibited from paying wages lower than the Minimum Wage. The meaning of employer in Article 1 number 4 of Law No.13 of 2003: is an individual, entrepreneur, legal entity, or other entities that employ workers by paying wages or other forms of remuneration. For professionals who employ workers, they are employers.

Not all notaries are able to pay wages of or greater than the UMP, this depends on how many clients who come to the notary. If the notary is not able to comply with the provisions of Article 90 No.13 of 2003, in this case a dispensation request can be submitted from the Manpower Office.

As a solution, if the honorarium is less than the Minimum Wage, a dispensation can be proposed to the Manpower Office or provide a premium if there is an increase in the number of clients. The notary can also do a mixed wage system, which is to determine the monthly base salary, plus a premium based on the amount of work done, including the number of deeds typed, or the number of clients.

The obligation of a notary / PPAT to keep the Minuta Deed secret is conveyed to its employees through a written or oral work agreement. The obligation to keep the notary protocol and the minimum deed as stipulated in Article 1 paragraph (1) UUJN is the obligation of the notary public. Even though notary employees are not a notary public, they are still obliged to keep the notary protocol secret, because notary employees are notary's representatives in the typing process and serving the clients. Therefore, alumni as notaries / PPAT should be obliged to convey the obligation to keep the minuta deed secret to avoid violating Article 16 paragraph (1) of the UUJN.

Employees at a notary / PPAT office are workers who have a profession, notary public, and PPAT as an employer, so the provisions of the Manpower Law apply in their work relationship. According to Iman Soepomo, job protection in general consists of 3 aspects, namely: 1 . protection of social aspects; 2. Protection of economic aspects; 3. Protection of technical aspects [3].

Protection of social aspects is protection that aims to respect workers / employees / laborers as human beings 
who have human rights. The scope of protection for social aspects includes limits on working hours, rest time, leave, permits, protection for women workers, overtime work, protection for child workers, protection for persons with disabilities.

Protection of economic aspects is a protection which aimed at the welfare of workers / employees / laborers and their families in order to avoid poverty. The scope of protection for economic aspects includes: wages / salaries, honoraria, overtime pay; permitted non-work wages; labor insurance, which later became known as social security for workers or BPJS Ketenagakerjaan; Religious holiday allowance (THR); Cooperative.

Protection of technical aspects is a protection aimed at protecting workers / employees / laborers to feel comfortable and safe in doing work. This protection includes Occupational Health and Safety. Technical aspect protection is rarely given to Notary and PPAT employees, since their jobs are generally administrative.

Notary / PPAT must be able to provide a holiday schedule for its employees. The types of holiday schedules according to the Manpower Regulations include; weekly holidays, annual leave, national holidays, holidays for important reasons like illness. The provision of a holiday schedule is an implication of protecting social aspects.

The number of working hours is based on Article 77 of Law No.13 of 2003, that the number of working hours per day is 7 (seven) hours for 6 (six) working days or 8 (eight) hours / day for 5 (five) working days. Due to the practice of the notary office of PPAT, which lasts 6 working days, the working time limit is 7 hours every day, except for Saturdays, 5 hours / day.

Excess working hours are included in overtime work, so according to the provisions of Article 78 of Law 13 of 2003, that exceed working hours that is over toward the Article 77, overtime pay must be paid. The amount of overtime pay is regulated in the Minister of Manpower Regulation No. 102 / MEN / VI / 2004 concerning Overtime Time and Overtime Wages.

The increasing salary should be paid if the income amount of the Notary / PPAT office increases than usual, or does overtime work. However, very few respondents do not get overtime pay even though they work overtime.

The existence of a salary when not working without notifying the boss can give a warning from the boss. If an employee does not enter the office because he asks for permission, then the salary is not deducted.

Specific provisions concerning Termination of Employment (PHK) that is applied are based on the provisions in the labor regulations. Notary / PPAT can make special regulations, through a work agreement. The termination clause, which is stated on the work agreement, may apply to the parties as long as it does not disobey the law.

\section{CONCLUSION}

1. The quality of Masters Alumni graduates in a horizontal user perspective is strongly influenced by the following factors: 1 . Professionalism and skills; 2. Attitude and behavior; 3. Accessibility and flexibility; 4. Reliability and Trustworthiness; 5. Reputation and Creadibiliy. 6.The precautionary principle.

2. The quality of Masters Alumni graduates in the perspective of a vertical user as their superior is strongly influenced by factors: ethics, discipline, ability to use digital technology, loyalty to superiors. Meanwhile, from users as subordinate to alumni, the quality of graduation is greatly influenced by: alumni guidance to their employees; loyalty to workers / employees; provision of worker welfare; protection of the workers, social aspects of work protection.

\section{SUGGESTION}

1. Alumni need to understand more about work relations to create a harmonious working relationship.

2. For notarial master study program, work relations course material in the office management course is required.

\section{REFERENCES}

[1] KBBI online

[2] Denny Saputra and Sri Endah Wahyuningsih, Principles of Prudence for Notaries / PPAT in Carrying Out Their Tupoks in Efforts to Prevent Crime, Akta Journal, Vol.4 No.3 of 2017, Faculty of Law UNISSULA, Lampung, p. 351

[3] Iman Soepomo, as quoted by Abdul Kkakim, 2007, Indonesian Manpower Law, PT. Citra Aditya Bakti, Bandung, p. 106 